2 - ORIGINAL ARTICLE

\title{
Ligation of the abdominal esophagus decreases scorpion toxin-induced gastric secretion in rats ${ }^{1}$
}

Ligadura do esôfago abdominal diminui a secreção gástrica induzida por toxina de escorpião em ratos

\author{
Claudia S. Vidal ${ }^{2}$, Marcus Vinicius Melo Andrade ${ }^{3}$, Gisele Viana ${ }^{4}$, Alcino L. Silva ${ }^{5}$, \\ Tasso Moraes-Santos ${ }^{5}$, Heloísa M. S. Gonzaga ${ }^{6}$, José Renan Cunha-Melo ${ }^{7}$
}

1. Surgical Physiopathology Laboratory. Faculty of Medicine Federal University of Minas Gerais (UFMG).

2. MD. Faculty of Medicine Federal University of Minas Gerais (UFMG).

3. PhD. Faculty of Medicine São Paulo University (FMUSP). Associate Prof., Department of Medicine - UFMG.

4. Master of Medicine. State University of Campinas (UNICAMP).

5. PhD of Medicine. Full Professor Department of Surgery, Faculty of Medicine - UFMG.

6. PhD of Biological Sciences. Full Professor Food Department, Faculty of Pharmacy - UFMG.

7. PhD of Medicine. Full Professor Department of Surgery, Faculty of Medicine - UFMG.

\section{ABSTRACT}

PURPOSE: Scorpion toxin purified from Tityus serrulatus venom (Tx) induces an increase in volume, acidity and pepsin secretion in the gastric juice of rats. Ligation of oesophagus has been shown to reduce the acid gastric secretion in rats. The aim of this paper was to determine the influence of the esophageal ligation on gastric secretion induced by Tx in rats

METHODS: Forty-four male albino rats were given water ad libitum, but no food for 20 to 24 hours, anesthetized with urethane and the trachea and jugular vein cannulated. Cervical or abdominal esophageal ligation or sham-operations were performed before and after the injection of $0.25 \mathrm{mg} / \mathrm{kg}$ of scorpion toxin (fraction T1) into the jugular vein. One hour later, the volume, acidity, $\mathrm{pH}$ and peptic activity of gastric juice were determined.

RESULTS: The scorpion toxin induced an increase in gastric juice volume, acidity and pepsin output and a decrease in $\mathrm{pH}$ when injected into the vein of intact animals or in sham-operated animals. Cervical esophagus ligation did not interfere with the effects of toxin, however, ligation of the abdominal esophageal decreased the toxin effect on the rat stomach.

CONCLUSION: Ligation of the abdominal esophagus decreases the gastric secretion induced by scorpion toxin.

Key words: Tityus serrulatus. Scorpion venoms. Gastric secretion. Esophageal ligation. 


\section{RESUMO}

OBJETIVO: A toxina de escorpião purificada do veneno do escorpião Tityus serrulatus (Tx) induz um aumento no volume, acidez e secreção de pepsina no suco gástrico de ratos. A ligadura do esôfago diminui a secreção ácida do estômago em ratos. O objetivo deste trabalho foi determinar a influência da ligadura do esôfago sobre a secreção gástrica induzida pela Tx em ratos. MÉTODOS: 44 ratos machos, brancos foram administrados água ad libitum, mas não alimentados por 20 a 24 horas, anestesiados com uretana e canulados a traquéia e a veia jugular. Foram realizadas as ligaduras do esôfago cervical ou abdominal ou operações simuladas antes e após a administração na veia jugular de $0,25 \mathrm{mg} / \mathrm{kg}$ de toxina de escorpião (fração T1). Uma hora após foram determinados o volume, acidez, $\mathrm{pH}$ e atividade péptica do suco gástrico.

RESULTADOS: A toxina de escorpião induziu um aumento do volume do suco gástrico, da acidez gástrica e da produção de pepsina e uma diminuição do $\mathrm{pH}$ quando injetada na veia de animais não operados ou com operação simulada. A ligadura do esôfago cervical não interferiu nos efeitos da toxina, enquanto a ligadura do esôfago abdominal diminuiu os efeitos da toxina no estômago do rato.

CONCLUSÃO: A ligadura do esôfago abdominal diminui a secreção gástrica estimulada pela toxina de escorpião.

Descritores: Tityus serrulatus. Veneno de escorpião. Secreção gástrica. Ligadura do esôfago.

\section{Introduction}

The symptoms of scorpion poisoning in humans and animals include arterial hypertension, cardiac and respiratory arrhythmias, pulmonary edema, nausea, vomiting, salivation and abdominal pain $^{1,2,3}$.

Intravenous administration of purified toxin ( $\mathrm{T} 1$ fraction) from the venom of scorpion Tityus serrulatus in anesthetized rats induces an increase in volume, acid output and peptic activity of gastric juice $e^{4,5}$, acute ulcers in the gastric mucosa ${ }^{6}$, hypergastrinemia ${ }^{7}$ and decrease of gastric emptying time ${ }^{8}$. Experiments have shown that the mechanism of action of the purified scorpion toxin on gastric secretion seems to be secondary to depolarization of post-ganglionic parasympathetic nerve endings in the stomach wall, leading to release of acetylcholine ${ }^{4}$ and stimulation of histamine and gastrin secretion ${ }^{9,10}$. Scorpion toxin also induces intense salivary secretion, acting through a and $B$ adrenergic receptors, and/or muscarinic receptors ${ }^{11}$. 
Gastric surgeries, such as vagotomy and antrectomy, are known to interfere with the mechanism of gastric secretion. A ligature placed around both the vagus nerves and the esophagus results in a greater reduction of the volume of gastric juice and a lower $\mathrm{pH}$ than bilateral vagotomy $^{12}$. This was explained by two hypotheses: the ligation of the esophagus obstructed the salivary flow into the stomach and thus prevented dilution and buffering of the gastric juice, or the ligation induced a greater interruption of vagus impulses to the stomach. The suppression of salivary submandibular gland leads to a decrease in vagal-induced gastric secretion ${ }^{13,14}$. The higher salivary $\mathrm{pH}$, as compared to gastric $\mathrm{pH}$, might interfere with the measurements of gastric acid and pepsin outputs. Preliminary data showed that ligation of the abdominal esophagus reduces gastric secretion and acidity in scorpion toxin-treated rats. The data obtained after cervical esophageal ligation, in contrast, suggest that the absence of saliva cannot account for the decreased gastric secretion in scorpion toxin-treated animals because, in this group of animals, the scorpion toxininduced gastric secretion was not different from the sham-operated or control intact rats.

This study was designed to investigate the influence of cervical and abdominal esophageal ligation on the gastric secretion induced by Tityus serrulatus scorpion toxin (fraction T1) in anesthetized rats.

\section{Methods}

The T1 fraction was obtained from Tityus serrulatus scorpion venom and purified by Sephadex G-25 chromatography ${ }^{15}$. Forty-four male albino rats (150 to $250 \mathrm{~g}$ ), divided into 6 groups (see Table 1 for groups specifications) of at least six animals each, were fasted but allowed free access to tap water for 20 to 24 hours before the experiments. The use of the rats followed the Council for International Organization of Medical Sciences (CIOMS) ethical code for animal experimentation and was previously approved by the Institutional Board for Research with Animals at the Federal University of Minas Gerais. The animals were anesthetized with urethane $(1.4 \mathrm{~g} / \mathrm{kg}$, i.p.) and the trachea and jugular vein were cannulated with polyethylene tubing. Surgeries were 
performed on 4 of the 6 groups. Cervical or abdominal esophageal ligation was performed after separating both right and left vagal trunks to avoid them being ligated. Sham-operations at cervical or abdominal regions were also done in two additional groups of rats. The remaining 2 groups were comprised of intact animals injected with saline (control group) or with $\mathrm{Tx}$. The partially purified $\mathrm{T} 1$ fraction $(0.25 \mathrm{mg} / \mathrm{kg})$ or a corresponding volume of saline solution was injected into the right jugular vein. One hour after the injection of saline or toxin, the abdomen was opened, the distal esophagus and pylorus were tied off and the stomach was resected. An incision was made in the greater curvature and the gastric juice collected into a beaker. Volume, $\mathrm{pH}$, acidity and peptic activity were measured. The $\mathrm{pH}$ was determined in a pH meter ( $\mathrm{pH}$ Metrohm, model E $350 \mathrm{~B}$ ), acid concentration was determined by tritration against $0.1 \mathrm{~N} \mathrm{NaOH}$ using phenolphthalein as an indicator and peptic activity was estimated by minor modifications ${ }^{16}$ of the procedure of Anson ${ }^{17}$. The samples were diluted 1:100 in 0.01N HCL. The experiments were performed in accordance with the Federal University of Minas Gerais guide for the care and use of laboratory animals.

\section{Statistical analysis}

All results are expressed as means \pm SEM. Statistical analysis was performed by analysis of variance. Multiple comparisons between means were made by the Duncan new multiple range test with values of $\mathrm{P}<0.05$ being considered significant.

\section{Results}

Cervical esophagus ligature does not interfere with the effect of scorpion toxin on gastric secretion

Ligation of the cervical esophagus followed by injection of scorpion toxin caused a decrease in $\mathrm{pH}$ and an increase in volume and in acid and peptic activity of the gastric juice, which did not differ from the increases observed either in intact or in sham-operated rats that underwent 
manipulation of cervical esophagus, and injection with toxin (Table 1). These groups of animals were significantly different from the group of intact animals injected with saline (Table 1).

\section{Abdominal esophagus ligation decreases the toxin-induced gastric secretion}

Rats that received abdominal esophagus ligation and injection with toxin showed a greater $\mathrm{pH}$ and a lesser increase in volume, acidity and peptic activity of gastric juice as compared to intact or sham-operated rats injected with toxin $(\mathrm{P}<0.05)$. In the group of animals submitted to shamoperation the effect of toxin on the parameters studied was even more pronounced than those observed in the intact group injected with toxin (Table 1). 
TABLE 1 - Effects of scorpion toxin (fraction T1) on the gastric secretion of anesthetized rats submitted to esophageal ligation.

\begin{tabular}{lcc|c|c}
\hline \multicolumn{1}{c|}{ Groups } & $\begin{array}{c}\text { Volume } \\
(\mathrm{ml})\end{array}$ & $\mathrm{pH}$ & $\begin{array}{c}\text { Acidity } \\
(\mu \mathrm{Eq} / \mathrm{h})\end{array}$ & $\begin{array}{c}\text { Pepsin } \\
(\mu \mathrm{M} \text { Mles } / \mathrm{h})\end{array}$ \\
\hline Int + Sal & $0.3 \pm 0.0$ & $3.15 \pm 0.1$ & $14.4 \pm 1.5$ & $1.3 \pm 0.2$ \\
Int + Tx & $1.8 \pm 0.1^{*}$ & $1.7 \pm 0.0^{*}$ & $174.1 \pm 4.5^{*}$ & $20.0 \pm 1.7^{*}$ \\
Sham cerv+ Tx & $1.7 \pm 0.2^{*}$ & $1.7 \pm 0.1^{*}$ & $140.0 \pm 13.9^{*}$ & $19.0 \pm 3.0^{*}$ \\
& & & & \\
Cerv EL + Tx & $1.7 \pm 0.4^{*}$ & $1.7 \pm 0.2^{*}$ & $136.7 \pm 28.3^{*}$ & $20.4 \pm 5.3^{*}$ \\
& & & & \\
Sham abd+ Tx & $2.6 \pm 0.2^{* *}$ & $1.3 \pm 0.1^{* *}$ & $276.1 \pm 45.6^{* *}$ & $27.2 \pm 1.0^{* *}$ \\
Ab EL + Tx & $1.2 \pm 0.1^{* *}$ & $2.0 \pm 0.1^{*}$ & $75.7 \pm 9.9^{* *}$ & $15.9 \pm 3.2^{*}$ \\
\hline
\end{tabular}

Int $+\mathrm{Sal}=$ Intact rats injected with saline $(\mathrm{N}=8)$

Int $+\mathrm{Tx}=$ Intact rats injected with scorpion toxin $(0,25 \mathrm{mg} / \mathrm{kg}) \mathrm{N}=8$.

Sham cerv $+\mathrm{Tx}=$ Sham-operated rats with manipulation of cervical esophagus and injected with scorpion toxin $(0.25 \mathrm{mg} / \mathrm{kg}), \mathrm{N}=6$.

CervEL $+\mathrm{Tx}=$ Rats with ligation of the cervical esophagus and injected with scorpion toxin $(0.25 \mathrm{mg} / \mathrm{kg}), \mathrm{N}=$ 6

Sham abd $+\mathrm{Tx}=$ Sham-operated rats with manipulation of esophago-gastric region and injected with scorpion toxin $(0.25 \mathrm{mg} / \mathrm{kg}), \mathrm{N}=6$.

AbdEL $+\mathrm{Tx}=$ Rats with ligation of the abdominal esophagus and injected with scorpion toxin $(0,25 \mathrm{mg} / \mathrm{kg})$,

$\mathrm{N}=10$.

Saline and scorpion toxin were injected by i.v. route.

Anesthesia: urethane $(1,4 \mathrm{~g} / \mathrm{kg}$, i.p.)

*Significantly different from intact animals injected with saline $(\mathrm{P}<0,05)$.

**Significantly different from intact animals injected either with saline or with scorpion toxin $(\mathrm{P}<0,05)$. 


\section{Discussion}

Cervical esophagus ligation blocked the flow of saliva to the stomach without changing the gastric secretory response induced by scorpion toxin in intact or sham-operated rats. This suggests that copious salivary secretion, as observed in scorpion toxin-intoxicated animals, is not efficacious in neutralizing gastric secretion induced by scorpion toxin. It has been shown that salivary gland ablation increases the incidence of gastric ulceration in rats ${ }^{13}$. Ligation of the salivary gland ducts decreases gastric acid secretion and the resistance of gastric mucosa to pentagastrin and to pharmacological stimulation ${ }^{14}$. In our experiment, the absence of saliva in the stomach, caused by cervical esophagus ligature did not alter the toxin-induced gastric secretory response, suggesting that the buffering action of the saliva on gastric juice does not seem effective in impairing toxininduced gastric secretion.

Abdominal esophageal ligation caused a significant decrease in toxin-induced gastric secretion. After ligation of the esophagus, just above the gastroesophageal junction, a decrease in volume of gastric secretion, in acidity and in peptic activity of the gastric juice was observed after toxin injection. These effects are not secondary to the interruption of the salivary flow to the stomach because cervical esophageal ligation, which also prevents the saliva from reaching the stomach, has no effect on gastric secretion in toxin-treated rats. The interruption of vagal fibers does not account for the decrease in gastric secretion, since the toxin acts on the postganglionic nerve fibers ${ }^{2,4,18,19}$, and cervical vagotomy was shown to be unable to alter the gastric secretory response to the toxin ${ }^{5}$. The surgical manipulation of the gastroesophageal junction (GEJ) also does not seem to be the cause for the decrease of gastric secretory response observed in the abdominal esophageal ligature group, since the sham-operated animals with manipulation of the esophagogastric region showed an even better response to the scorpion toxin than did the intact animals. Finally, one could postulate that the ligation of the abdominal esophagus would lead to ischemia of the proximal stomach but this is a very remote possibility, considering that the main vascular arterial pedicles to the stomach were preserved. 


\section{Conclusion}

The present study shows that abdominal, but not cervical esophageal ligation, partially blocks the effects of scorpion toxin on rat gastric secretion. The mechanisms of the inhibition induced by abdominal esophageal ligation deserve further investigation.

\section{References}

1. Freire-Maia L, Cunha-Melo JR, Azevedo AD, Barroso H. Mechanism of the pulmonary edema induced by intravenous injection of scorpion toxin in the rat. Agents Actions 1978;8:113-8.

2. Azevedo AD, Silva AB, Cunha-Melo JR, Freire-Maia L. Cardiovascular and respiratory effects induced by a purified scorpion toxin (tityustoxin) in anesthetized rats. Toxicon $1983 ; 21: 753-9$.

3. Freire-Maia L, Campos JA. Pathophysiology and treatment of scorpion poisoning. In: Ownby CL, Odell GV. Natural Toxins: Characterization, pharmacology and therapeutics. Oxford: Pergamon Press; 1989. p 139-59.

4. Gonzaga HMS, Alzamora F, Cunha-Melo JR, Freire-Maia L. Gastric secretion induced by scorpion toxin. Toxicon 1979;17:316-8.

5. Cunha-Melo JR, Gonzaga HMS, Alzamora F, Freire-Maia L. Effects of purified scorpion toxin (tityustoxin) on gastric secretion in the rat. Toxicon 1983;21:843-8.

6. Cunha-Melo JR, Toppa NH, Martins P, Colares CN, Castro YS, Freire-Maia L, Acute gastric mucosal injury induced by toxins from Tityus serrulatus venom: a novel experimental model in the rat. Toxicon 1991;29:1395-401.

7. Toppa NH, Martins P, Colares CN, Freire-Maia L, Cunha-Melo JR. Effect of Tityus serrulatus scorpion toxin on serum gastrin levels in anaesthetized rat. Toxicon 1998;36:1833-42. 
8. Troncon LEA, Santos AA, Garbacio VL, Secaf M, Verceze AV, Cunha-Melo JR.. Inhibition of gastric emptying and intestinal transit in anaesthetized rats by a Tityus serrulatus scorpion toxin. Braz J Med Biol Res 2000;33:1053-8.

9. Code CF. Histamine and gastric secretion: a later look. Fed. Proc. 1965;24:1311-21.

10. Cunha-Melo JR, Almeida AP, Gonzaga HMS, Gomez MV, Freire-Maia L. Effect of scorpion toxin on gastric histamine and acetilcholine content in the rat. Braz J Med Biol Res 1987;20:393-401.

11. Catanzaro OL, Santos RAS, Parra OM, Santos RM, Freire-Maia L, Beraldo WT. Effect of scorpion toxin (Tyityustoxin) on the salivary gland of the rat, in vivo and in vitro. Agents Actions 1978;8:119-24.

12. Madden RJ, Ramsburg HH, Hundley JM. A critical study of the Shay rat. Gastroenterology $1951 ; 18: 119-27$.

13. Barker JH, Lund JP, Dellow PG. Desalivation and the incidence of experimental gastric ulceration. Proc Can Biol Soc 1969;12:62.

14. Skinner KA, Tepperman BL. Influence of desalivation on acid secretion output and gastric mucosal integrity in the rat. Gastroenterology 1981;84:355-9.

15. Gomez MV, Diniz CR. Separation of toxic components from the Brazilian scorpion Tityus serrulatus. Mem Inst Butantan 1966;33:899-902.

16. Berstad A. A modified hemoglobin method for the stimulation of pepsin in gastric juice. Scand J Gastroenterol 1970;5:343-8.

17. Anson ML. The stimulation of pepsin, trypsin, and cathepsin with hemoglobin. J Gen Physiol 1938;22:79.

18. Diniz CR, Torres JM. Release of acetylcholine-like substance from guinea pig ileum by scorpion venom. Toxicon 1968;5:277-81.

19. Freire-Maia L, Cunha-Melo JR, Futuro Neto HA, Azevedo AD, Weinberg J. Cholinergic and adrenergic effects of tityustoxin. Gen Pharmacol 1976;7:115-21. 
Correspondence:

Prof. José Renan Cunha-Melo

Universidade Federal de Minas Gerais

Faculdade de Medicina/Departamento de Cirurgia

Av. Alfredo Balena, 190

30130-100 Belo Horizonte - MG

Tel.: (31)3248-9931

ircmelo@medicina.ufmg.br

Data do recebimento: 18/03/2004

Data da revisão: 02/04/2004

Data da aprovação: 23/04/2004

Conflict of interest: none

Financial source: CAPES, CNPq, FAPEMIG

\section{How to cite this article:}

Vidal CS, Andrade MVM, Viana G, Silva AL, Moraes-Santos T, Gonzaga HMS, Cunha-Melo JR. Ligation of the abdominal esophagus decreases scorpion toxin-induced gastric secretion in rats. Acta Cir Bras [serial online] 2004 May-Jun;19(3). Available from URL: http://www.scielo.br/acb [also in CD-ROM]. 